\title{
10. EOCENE BENTHIC FORAMINIFERS FROM THE UPPER CONTINENTAL RISE OFF NEW JERSEY, DEEP SEA DRILLING PROJECT SITE 605 ${ }^{1}$
}

\author{
R. E. Hulsbos, Instituut voor Aardwetenschappen, Vrije Universiteit, Amsterdam²
}

\begin{abstract}
This paper describes and illustrates early to middle Eocene benthic foraminifers from northwest Atlantic Site 605 , on the continental rise off New Jersey. Benthic foraminiferal faunas are dominated by Bulimina spp., Nuttallides truempyi, Lenticulina spp., and Cibicidoides spp. Other common taxa include Oridorsalis spp., Gyroidinoides spp., uniserial taxa, arenaceous taxa, and Globocassidulina subglobosa. Together, these taxa usually make up $70 \%$ or more of the total fauna. The assemblages are interpreted as indicating a lower bathyal environment of deposition during the Eocene at Site 605 . This is corroborated by an independent water depth estimate through backstripping, indicating a water depth for the beginning of the Eocene to late middle Eocene of approximately 2300 to $2000 \mathrm{~m}$.
\end{abstract}

\section{INTRODUCTION}

This chapter describes Eocene benthic foraminiferal faunas from Site 605 . Site $605\left(38^{\circ} 44.53^{\prime} \mathrm{N}, 72^{\circ} 36.55^{\prime} \mathrm{W}\right)$ is located on the upper continental rise, $180 \mathrm{~km}$ westsouthwest of Atlantic City (New Jersey) at a water depth of $2194 \mathrm{~m}$, in an intercanyon area between the large Hudson and Wilmington canyon systems (Fig. 1).

The stratigraphy of Site 605 is summarized in Figure 2. A stratigraphically complete sequence of lower Eocene to lower middle Eocene sediments was recovered. The Eocene sequence can be divided into two (local) lithostratigraphic units (Fig. 2). The upper unit (Unit II) is composed of $153 \mathrm{~m}$ of lower middle Eocene biosiliceous nannofossil chalk rich in radiolarians and diatoms. The lower unit (Unit III) consists of $214 \mathrm{~m}$ of lower Eocene to lowest middle Eocene greenish gray nannofossil limestone, with varying amounts of foraminifers and calcified radiolarians. The boundary between the two units is not a visually apparent lithologic break, but is defined by a dramatic upward increase in biogenic silica components. No significant biostratigraphic break was identified at this boundary. The apparent increase in productivity from Unit III to Unit II has been attributed by the Shipboard Scientific Party to upwelling associated with the onset of the Labrador Current in this area. For a more detailed lithologic description the reader is referred to the Site 605 chapter (this volume).

\section{MATERIALS AND METHODS}

Because sediments were indurated, especially in the lower part of the sequence, a rather vigorous method was needed to disintegrate the samples. Samples were dried, saturated with petroleum ether, and covered with hot water, which caused the petroleum ether to boil, thereby disintegrating the sediment. The residues were then washed over a $65-\mu \mathrm{m}$ sieve. Preservation of foraminifers is often poor, especially in residues from Unit III, where recrystallized foraminifers commonly have calcite overgrowth. In the upper unit (Unit II) preservation is better, but

\footnotetext{
${ }^{1}$ van Hinte, J. E., Wise, S. W., Jr., et al., Init. Repts. DSDP, 93: Washington (U.S. Govt, Printing Office)

Address: c/o J. E. van Hinte, Instituut voor Aardwetenschappen, Vrije Universiteit,
} Postbus 7161, 1007 MC Amsterdam, The Netherlands. many foraminifers also show dissolution pitting and recrystallization The study material is filed in the collection of the Stratigraphy/Paleontology Department of the Institute of Earth Sciences, Free University, Amsterdam.

Study of Eocene benthic foraminiferal faunas at Site 605 was limited to 38 samples, mainly core-catcher samples taken aboard ship. For the main objective of this paper (description and illustration of Eocene benthic foraminifers present at Site 605), satisfactory results were obtained by the analysis of core-catcher samples only. Poor foraminiferal preservation, especially in the lower part of the section (Unit III, Samples $605-22, C C$ to -43, CC) limited identification of foraminifers and did not warrant detailed investigations of more samples. In the lowermost part of the section (Samples $605-28, C C$ to $-43, C C$ ), only a qualitative analysis was possible. From the residues with better foraminiferal preservation (Samples 605-6,CC to $-27, \mathrm{CC}$ ), a representative split was picked for about 200-300 benthic foraminifers. In many cases the number was not reached and the whole residue was picked.

\section{SPECIES DISTRIBUTION}

Distribution of the identified taxa is shown in Table 1, which also shows nannofossil zones (after Applegate and Wise, this volume) and chronostratigraphy (after Berggren et al., 1985) for the Eocene section of Site 605, as well as a local biostratigraphic subdivision based on benthic foraminifers (see Discussion). Total numbers of specimens counted per sample and computed percentages for a number of selected taxa are presented in Table 2 .

Benthic foraminiferal assemblages are dominated by Bulimina spp., Nuttallides truempyi, Lenticulina spp., and Cibicidoides spp. (mostly $C$. tuxpamensis and $C$. ungerianus) (Table 2). Other common and long-ranging taxa are Oridorsalis spp. (mostly O. umbonatus), Gyroidinoides spp., Globocassidulina subglobosa, Stilostomella spp., Nodosaria-Dentalina spp. and arenaceous taxa. Together, these taxa usually make up $70 \%$ or more of the total fauna (Table 2). They range throughout the Eocene section. Frequently occurring but less abundant taxa include Pullenia quinqueloba, Nonion havanense, Spiroplectammina spectabilis, and Vulvulina spp. (mostly $V$. spinosa). Diagnostic species of the upper part of the section (Unit II) are Pullenia eocenica, Alabamina dissonata, Gavelinella micra, Plectina elongata, and Uvigerina spp. Confined to the lower part of the section (Unit III) are Tappanina selmensis, Abyssamina poagi, and Glomospira charoides. Gaudryina spp. (G. sp. cf. G. laevi- 


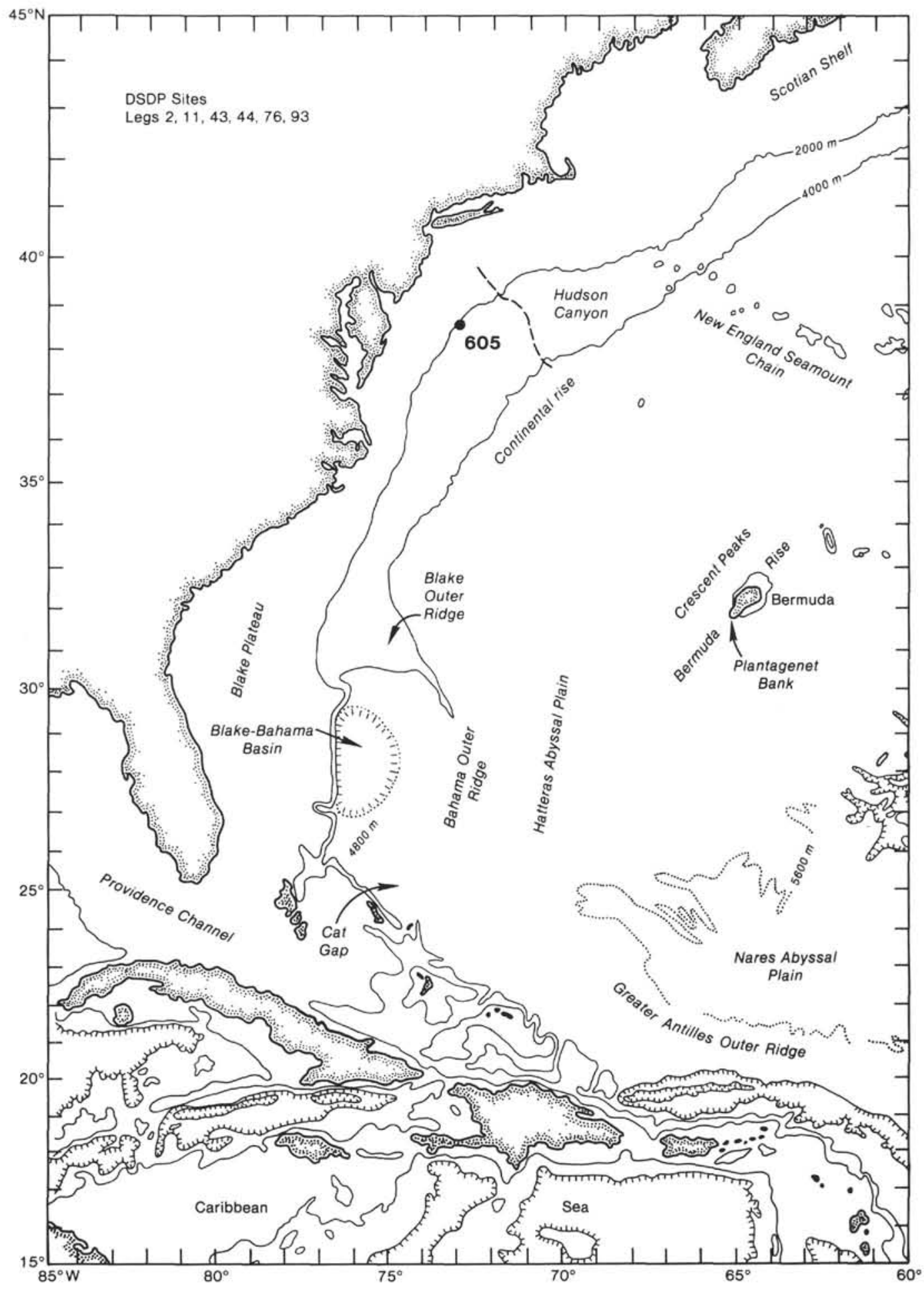

Figure 1. Location of Site 605.

gata and $G$. pyramidata) are present in both units, but occur more frequently in Unit III. Aragonia spp. and Hanzawaia cushmani display a brief peak of high abundance (up to $20 \%$ ) near the base of Unit II. Accessory species include Pleurostomella spp. Orthomorphina spp., Chrysalogonium spp., Ellipsoglandulina spp., Trifarina wilcoxensis, and polymorphinids.

The ratio of planktonic to benthic foraminifers is uniform for all samples. Benthic foraminifers usually com- prise about $3 \%$ of the foraminiferal fauna but occasionally reach $6-7 \%$. This suggests normal pelagic sedimentation during the Eocene, with deposition above the calcite compensation depth (CCD).

\section{DISCUSSION}

As a result of the Deep Sea Drilling Project, Tertiary benthic foraminifers are now widely used in biostratigraphy, paleobiogeography, and paleoecology (Berggren, 


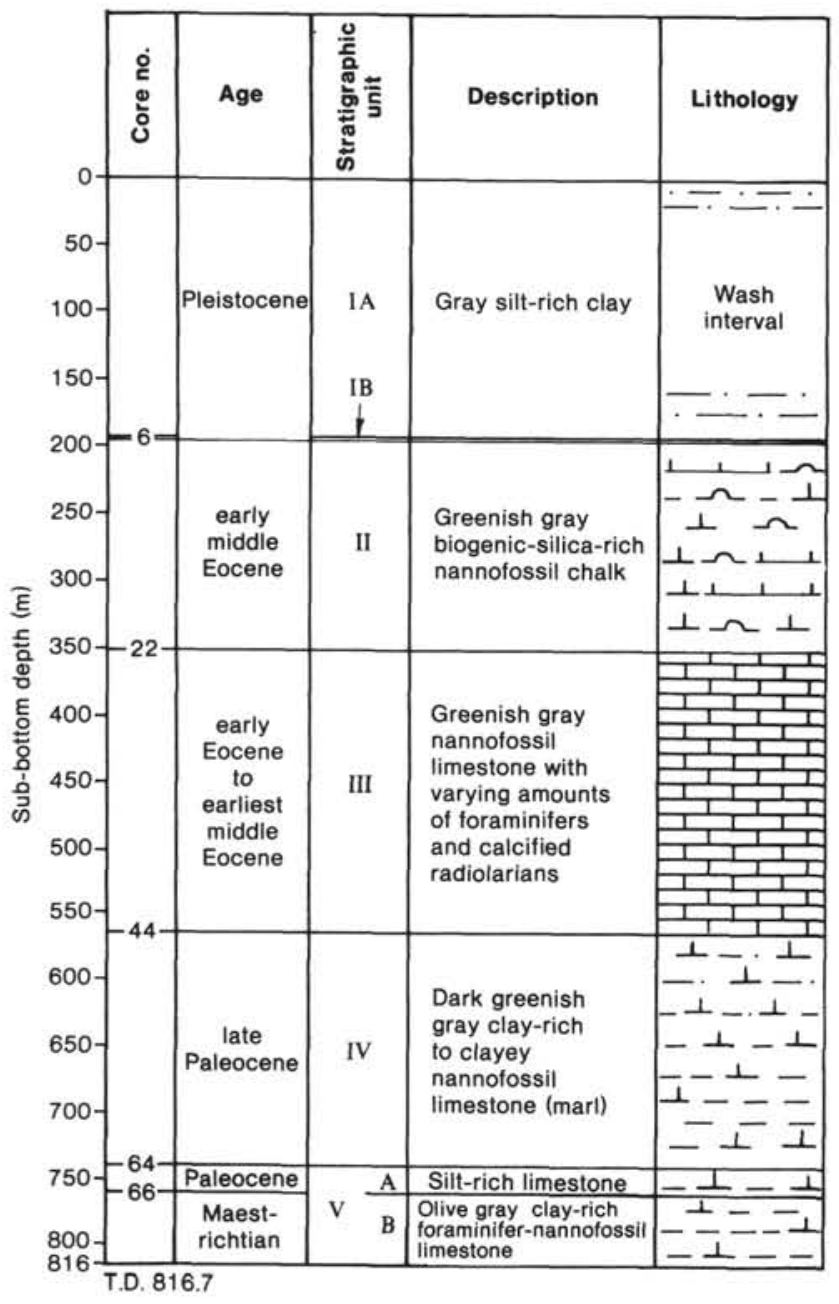

Figure 2. Stratigraphic summary of Site 605 .

1972; Douglas, 1973; Resig, 1976; Boersma, 1977; Proto-Decima and Bolli, 1978; Schnitker, 1979; Corliss, 1981; Tjalsma and Lohmann, 1983; Miller, 1983; Miller et al., 1985). Unfortunately, their use is somewhat limited, primarily by the lack of a solid taxonomic base to provide the framework for paleoenvironmental interpretations. However, much progress has been made by Berggren and Aubert (1975) for the Paleocene Midway-type fauna, and by Tjalsma and Lohmann (1983) for Paleocene-Eocene bathyal and abyssal faunas of the South Atlantic and Caribbean. This paper follows the taxonomy of Tjalsma and Lohmann (1983).

Use of benthic foraminifers as index fossils to supplement planktonic foraminiferal biostratigraphy in deepsea strata is limited by the relatively long stratigraphic ranges, irregular stratigraphic occurrences, and low frequencies of most taxa; these hamper the use of their extinction levels as markers (Boltovskoy, 1980). Tjalsma and Lohmann (1983) found it difficult to establish biochronostratigraphic subdivisions based on benthic foraminifers for the Paleocene-Eocene of the South Atlantic, and they proposed only informal biostratigraphic "associations" for the Paleocene and earliest Eocene. Such problems are clearly seen on the distribution chart for the Eocene of Site 605 (Table 1). Most taxa that occur persistently are long-ranging. A local subdivision based on conspicuous and (in this section) short-ranging species like Abyssamina poagi, Alabamina dissonata, Bulimina macilenta, and Hanzawaia cushmani would be of little value for chronostratigraphic purposes, because all have been reported to range through most of the Eocene.

Another problem noted by Tjalsma and Lohmann (1983) is that the depth ranges of a number of taxa change through time, resulting in different biostratigraphic ranges at different depths. This would make it necessary to erect at least two different zonal schemes (one for bathyal and one for abyssal depths), and each zonal scheme would still suffer from the drawbacks just mentioned. Nevertheless, benthic foraminifers can be useful in biostratigraphy if they are calibrated against planktonic foraminiferal zonations to develop a composite range chart showing maximum ranges of species at both shallow and deep sites. Such calibration allows gross division (at the stage or series level) of a section by means of benthic foraminifers, which can be helpful in the absence of planktonic foraminifers. A more refined, formal biostratigraphy based on benthic foraminifers does not seem feasible.

Benthic foraminifers have, however, been useful in paleoceanographic and paleobathymetric interpretations, because of their relative morphologic stability and wide geographic distribution. A number of faunal changes related to paleoceanographic changes have been established for the Paleogene interval in the Atlantic Ocean (Schnitker, 1979; Corliss, 1981; Tjalsma and Lohmann, 1983; Snyder et al., 1985; Miller et al., 1985). The most important Eocene changes include a rapid faunal turnover around the Paleocene/Eocene boundary (compare also Saint-Marc, this volume) and the gradual replacement of a Nuttallides truempyi assemblage (and eventual extinction of $N$. truempyi at the end of the Eocene) by a Globocassidulina subglobosa-Gyroidinoides-Cibicidoides ungerianus-Oridorsalis umbonatus assemblage from the early middle Eocene on. This assemblage of stratigraphically long-ranging and bathymetrically wideranging taxa continues into the Oligocene. The late middle Eocene to Pleistocene hiatus at Site 605 prevents recognition of this late Eocene faunal change at Site 605.

Local subdivision of a section by means of benthic foraminifers can be useful, because it may delineate changes in paleoenvironmental factors. Combined with data from other sources, this may have (regional) chronostratigraphic value if the distribution of benthic taxa has been determined by a regional event. Three benthic foraminiferal units can be distinguished in the Eocene of Site 605 (Table 1): a lower and an upper one with characteristic faunal elements and a middle unit without exclusive species.

The upper boundary of the Abyssamina poagi/Tappanina selmensis Zone, stratigraphically lowest of the three, is defined by the last appearance of $A$. poagi. In addition to the nominate species, Gaudryina sp. cf. G. laevigata and $G$. pyramidata are characteristic species, although they are not confined to this zone. The lower 
Table 1. Distribution of early Eocene to early middle Eocene benthic foraminifers, Site 605 .

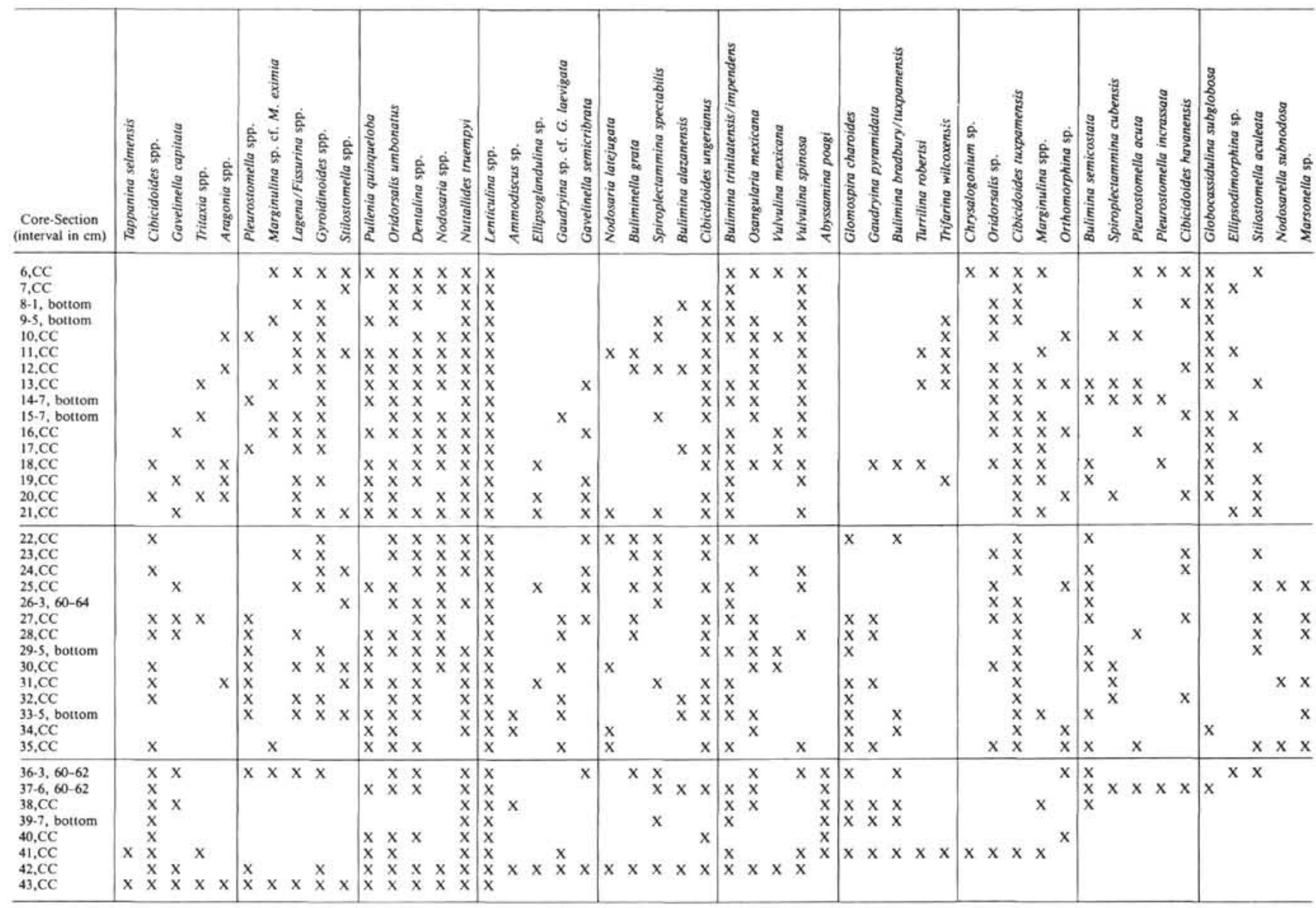

Note: Chronostratigraphy after Berggren et al., 1985.

boundary of the Pullenia eocenica/Uvigerina elongata Zone is defined by the first appearance of $P$. eocenica and $U$. elongata. Other characteristic species include $G a$ velinella micra, Alabamina dissonata, Plectina elongata, and Hanzawaia cushmani. The later two taxa are confined to this zone. Between these two zones the Stilostomella gracillima/Anomalina spissiformis Zone is characterized by the successive first appearances of many species, including most species of the genera Stilostomella and Cibicidoides, but lacks species that are confined to this zone.

The lower boundary of the $P$. eocenica/U. elongata Zone coincides with the change from lithostratigraphic Unit III to Unit II. This change is thought to be linked with an increase in productivity associated with the onset of the Labrador Current in this area (van Hinte, Wise, et al., 1985), but this is not clearly expressed in the benthic foraminiferal assemblages. A marked increase in species number was noted from Unit III (low twenties and teens) to Unit II (high twenties and thirties). However, there was no conspicuous change in relative abundances of taxa present in both units (Table 2), and one would rather expect the species number to decrease with an increase in trophic level. The change that did occur could very well be the product of differential preservation, but in that case one would also expect a change in $\mathrm{P} / \mathrm{B}$ ratios from Unit III to Unit II, and such a change was not observed.

Tjalsma and Lohmann (1983) distinguished two distinct depth assemblages for the South Atlantic Eocene: an abyssal assemblage dominated by Globocassidulina subglobosa, Gyroidinoides spp., Stilostomella aculeata, Oridorsalis umbonatus, and Cibicidoides ungerianus; and a (lower) bathyal assemblage with predominant elements including Lenticulina spp., Bulimina spp. (B. trinitatensis, B. tuxpamensis, B. semicostata), and Osangularia mexicana. The bathymetrically wide-ranging Oridorsalis spp., Gyroidinoides spp., G. subglobosa, and C. ungerianus are also dominant elements in this bathyal assemblage, whereas typical bathyal elements like lenticulinids and buliminids are absent or of only little importance in abyssal assemblages.

Cumulative percentages of typical bathyal and abyssal elements have been computed for the Eocene at Site 605 . Table 2 shows that in many samples percentages do not differ considerably. Also, the number of samples with dominant bathyal and abyssal elements, respective$\mathrm{ly}$, is about equal. A lower bathyal environment of deposition for the Eocene section at Site 605 is inferred from these results. Occasionally high percentages of ba- 
Table 1 (continued).

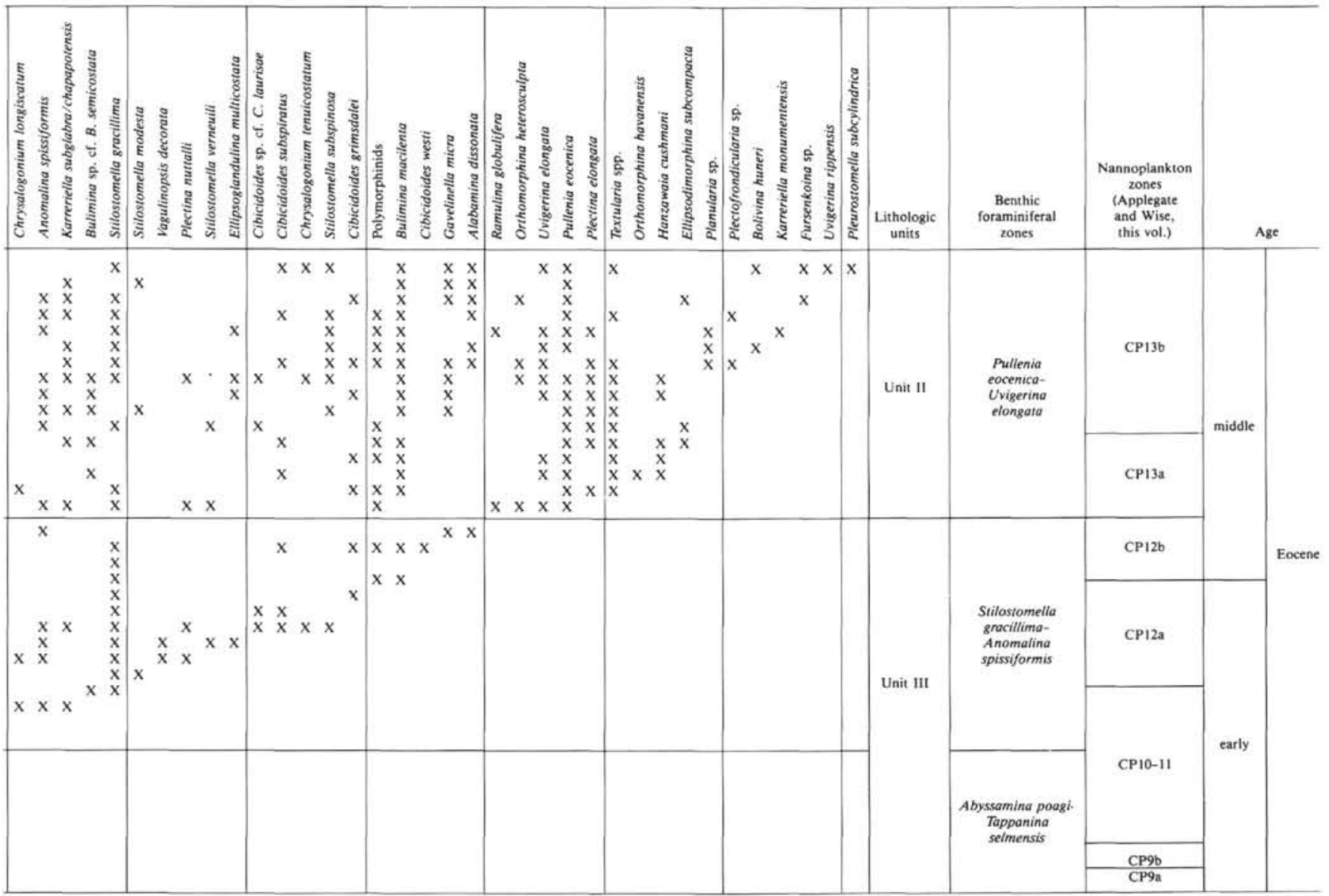

thyal elements (e.g., Sample 605-11,CC and 605-14-7, bottom) are considered to be due to downslope displacement. However, this interpretation remains tentative, as only a limited number of samples has been analyzed, and some samples had too few specimens to yield accurate percentage estimates for species abundance.

Nonetheless, confirmation of the usefulness of paleobathymetric interpretation based on benthic foraminifers can be found in an independent paleodepth estimate like the "backstripping" method. Subsidence at Site 605 during and after the Eocene was caused by sediment loading rather than by crustal cooling. Present depth below sea level of the base of early Eocene sediments is $2758 \mathrm{~m}$ (water depth of $2194 \mathrm{~m}$ plus $564 \mathrm{~m}$ post-Paleocene sediments). To obtain a depth for the Eocene, corrections have to be made for isostatic loading subsidence caused by younger sediments and for pseudosubsidence caused by compaction of older sediments. Using the equations of Hardenbol et al. (1981), one can estimate a depth for the beginning of the Eocene to late middle Eocene of approximately 2300 to $2000 \mathrm{~m}$. This is in good agreement with the lower bathyal environment of deposition suggested by the benthic foraminiferal faunas. Thus, our findings in the northwest Atlantic support the scheme of Tjalsma and Lohmann (1983) established in the South Atlantic.

\section{ANNOTATED SPECIES LIST}

In species identification the taxonomy outlined by Tjalsma and Lohmann (1983) is followed. Species are listed in alphabetical order of genus names.

Abyssamina poagi Schnitker and Tjalsma (Plate 1, Fig. 17). Schnitker and Tjalsma, 1980, p. 237, pl. 1, figs. 7-9. Rare. Restricted to Unit III.

Alabamina dissonata (Cushman and Renz) (Plate 5, Figs. 5, 6). Pulvinulinella atlantisae Cushman var. dissonata Cushman and Renz, 1948 , p. 35, pl. 7, figs. 11-12. Most specimens do not show a distinct keel. Rather common in Unit II (up to 9\%).

Anomalina spissiformis Cushman and Stainforth (Plate 4, Figs. 1, 2). Anominalina alazanensis Nuttall var. spissiformis Cushman and Stainforth, 1945 , p. 71 , pl. 14, figs. 5a-c. Represents up to $8 \%$ of the fauna.

Aragonia spp. Occur irregularly throughout the section. In Sample $605-10, \mathrm{CC}$ they constitute $20 \%$ of the fauna.

Bolivina huneri Howe (Plate 2, Fig. 4). Howe, 1939, p. 66, pl. 9 , figs. 3-4. This distinctive species has been found only in the top of the section. Rare.

Bulimina alazanensis Cushman (Plate 2, Fig. 3). Cushman, 1927a, p. 161 , pl. 25 , fig. 4 . Occurs irregularly throughout the section. Rare.

Bulimina impendens Parker and Bermudez (Plate 2, Figs. 6, 7) Parker and Bermudez, 1937, p. 514, pl. 58, figs. 7a-c. B. impendens differs from $B$. trinitatensis Cushman and Jarvis by the shorter and stouter shape of the test and the presence of irregular spines on the early chambers. These two species have not been differentiated, because they are difficult to distinguish in our material. Rather common. 
Table 2. Benthic foraminifers, Site 605 (percentages).

\begin{tabular}{|c|c|c|c|c|c|c|c|c|c|c|c|c|c|c|c|c|}
\hline \multicolumn{17}{|c|}{ Selected taxa } \\
\hline $\begin{array}{l}\text { Core-Section } \\
\text { (interval in cm) }\end{array}$ & $\begin{array}{c}\text { No. } \\
\text { counted }\end{array}$ & $\begin{array}{l}\text { Species } \\
\text { no. }\end{array}$ & $\begin{array}{l}\text { Lenticulina } \\
\text { spp. }\end{array}$ & N. truempyi & $\begin{array}{l}\text { Oridorsalis } \\
\text { spp. }\end{array}$ & G. subglobosa & $\begin{array}{l}\text { Gyroidinoides } \\
\text { spp. }\end{array}$ & $\begin{array}{l}\text { Bulimina } \\
\text { spp. }\end{array}$ & $\begin{array}{c}\text { Cibicidoides } \\
\text { spp. }\end{array}$ & C. ungerianus & $\begin{array}{l}\text { Dentalina/ } \\
\text { Nodosaria } \\
\text { spp. }\end{array}$ & $\begin{array}{l}\text { Stilostomella } \\
\text { spp. }\end{array}$ & $\begin{array}{l}\text { Arenaceous } \\
\text { spp. }\end{array}$ & $\begin{array}{c}\% \\
\text { Total }\end{array}$ & $\begin{array}{l}\text { Bathyal } \\
\text { elements } \\
\text { (\%) }\end{array}$ & $\begin{array}{c}\begin{array}{c}\text { Abyssal } \\
\text { elements }\end{array} \\
(\%)\end{array}$ \\
\hline $6, \mathrm{CC}$ & 381 & 37 & 8.4 & 5.3 & 20.2 & 3.2 & 4.8 & 8.6 & 4.2 & 0.0 & 7.6 & 2.4 & 0.5 & 65.2 & 17.3 & 28.4 \\
\hline $7, \mathrm{CC}$ & 48 & 17 & 8.3 & 2.1 & 2.1 & 20.8 & 0.0 & 18.8 & 6.3 & 0.0 & 8.3 & 4.2 & 8.0 & 78.9 & 27.1 & 22.0 \\
\hline $8-1$, bottom & 126 & 26 & 17.5 & 3.2 & 4.0 & 8.7 & 6.4 & 8.7 & 5.6 & 0.8 & 1.6 & 2.4 & 10.0 & 68.1 & 26.2 & 17.5 \\
\hline 9-5, bottom & 148 & 26 & 15.5 & 0.7 & 5.4 & 7.4 & 6.1 & 16.9 & 9.5 & 4.7 & 0.0 & 1.4 & 20.0 & 82.9 & 33.8 & 22.3 \\
\hline $10, \mathrm{CC}$ & 203 & 32 & 6.9 & 3.0 & 0.0 & 3.5 & 4.4 & 14.8 & 3.9 & 3.9 & 4.4 & 1.0 & 6.9 & 48.8 & 22.2 & 11.8 \\
\hline $11, \mathrm{CC}$ & 210 & 29 & 9.1 & 7.5 & 0.5 & 1.4 & 1.0 & 29.5 & 6.7 & 6.7 & 8.6 & 2.9 & 4.8 & 72.0 & 39.7 & 9.5 \\
\hline $12, \mathrm{CC}$ & 256 & 35 & 7.8 & 2.7 & 2.7 & 7.8 & 5.5 & 1.6 & 14.8 & 5.9 & 2.7 & 2.0 & 3.9 & 51.5 & 11.3 & 19.9 \\
\hline $13, \mathrm{CC}$ & 239 & 42 & 5.4 & 0.0 & 2.9 & 2.1 & 5.4 & 12.6 & 10.5 & 8.4 & 5.4 & 2.1 & 25.5 & 71.9 & 22.2 & 18.4 \\
\hline 14-7, bottom & 497 & 28 & 2.6 & 1.2 & 3.4 & 0.0 & 2.4 & 59.4 & 3.8 & 2.0 & 0.6 & 0.0 & 6.6 & 80.0 & 62.8 & 7.0 \\
\hline 15-7, bottom & 276 & 30 & 6.5 & 15.9 & 4.4 & 1.5 & 2.9 & 3.3 & 12.0 & 6.5 & 4.0 & 0.7 & 20.3 & 71.5 & 10.9 & 14.9 \\
\hline $16, \mathrm{CC}$ & 260 & 29 & 7.7 & 19.2 & 7.3 & 0.8 & 8.9 & 4.2 & 0.8 & 0.0 & 7.3 & 1.5 & 12.3 & 70.0 & 12.0 & 14.2 \\
\hline $17, \mathrm{CC}$ & 103 & 25 & 5.8 & 3.9 & 0.0 & 1.0 & 6.8 & 18.5 & 26.2 & 18.5 & 3.9 & 2.9 & 15.5 & 84.5 & 24.3 & 27.2 \\
\hline $18, \mathrm{CC}$ & 255 & 31 & 9.4 & 2.8 & 5.9 & 1.6 & 4.7 & 2.4 & 7.5 & 5.1 & 7.8 & 0.0 & 15.0 & 57.1 & 12.2 & 14.1 \\
\hline $19, \mathrm{CC}$ & 129 & 26 & 7.0 & 5.4 & 3.9 & 3.9 & 7.8 & 13.2 & 4.7 & 0.0 & 8.5 & 0.8 & 11.6 & 66.8 & 20.2 & 16.3 \\
\hline $20, \mathrm{CC}$ & 127 & 27 & 9.5 & 3.2 & 7.9 & 4.7 & 0.0 & 3.9 & 22.1 & 6.3 & 9.5 & 1.6 & 9.5 & 71.9 & 13.4 & 19.7 \\
\hline $21, \mathrm{CC}$ & 238 & 21 & 10.5 & 17.7 & 7.6 & 0.0 & 7.1 & 1.3 & 9.2 & 8.0 & 9.7 & 11.8 & 5.9 & 80.8 & 11.8 & 31.5 \\
\hline $22, \mathrm{CC}$ & 301 & 21 & 7.6 & 5.7 & 6.0 & 0.0 & 0.7 & 17.3 & 20.6 & 16.3 & 18.6 & 0.0 & 16.0 & 92.5 & 25.3 & 22.9 \\
\hline $23, \mathrm{CC}$ & 134 & 20 & 9.7 & 7.5 & 10.5 & 0.0 & 2.2 & 3.0 & 20.2 & 10.5 & 17.2 & 5.0 & 9.0 & 84.3 & 12.7 & 25.4 \\
\hline $24, \mathrm{CC}$ & 38 & 15 & 13.2 & 5.3 & 0.0 & 0.0 & 2.6 & 0.0 & 18.4 & 0.0 & 18.4 & 5.3 & 18.4 & 81.6 & 23.7 & 2.6 \\
\hline $25, \mathrm{CC}$ & 92 & 23 & 19.6 & 0.0 & 2.2 & 2.2 & 4.4 & 9.8 & 4.4 & 4.4 & 7.6 & 2.2 & 13.0 & 65.4 & 29.4 & 9.8 \\
\hline $26-3,60-64$ & 41 & 13 & 12.7 & 7.1 & 4.9 & 0.0 & 0.0 & 19.5 & 17.1 & 0.0 & 22.0 & 7.3 & 9.8 & 100 & 31.7 & 2.4 \\
\hline $27, \mathrm{CC}$ & 134 & 24 & 4.5 & 0.0 & 2.2 & 0.0 & 0.0 & 13.4 & 25.4 & 5.2 & 17.9 & 1.0 & 18.7 & 83.1 & 19.4 & 6.0 \\
\hline
\end{tabular}

Note: For Samples $605-28, \mathrm{CC}$ to $605-43, \mathrm{CC}$; no percentages were computed. The number of species for each sample is as follows:

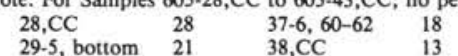

$\begin{array}{lll}29-5, \text { bottom } & 21 & 38, \text {, C } \\ 30, \text { CC } & 23 & 39-7 \text {, bottom }\end{array}$

$31 \mathrm{CC}$

$32, \mathrm{CC} \quad 18 \quad 40, \mathrm{CC}$

$\begin{array}{llll}33-5, \text { bottom } & 24 & 42, \mathrm{CC} & 23 \\ 34, \mathrm{CC} & 12 & 43, \mathrm{CC} & 16\end{array}$

36-3, 60-62 22

Bulimina spp. Osangularia mexicane.

Globocassidulina subglobosa, Oridorsalis umbonatus, Gyroidinoides spp., Cibicidoides ungerianus, Stilostomella aculeate. 
Bulimina macilenta Cushman and Parker (Plate 2, Fig. 8). Bulimina denticulata Cushman and Parker, 1936, p. 42, pl. 7, figs. 7a-8c. Bulimina macilenta Cushman and Parker, 1939 (new name), p. 93. Rather common from Sample 605-25,CC upward.

Bulimina semicostata Nuttall (Plate 2, Figs. 1 and 2). Nuttall, 1930, p. 285 , pl. 23 , figs. $15-16$. Occurs irregularly throughout the section. Forms assigned to $B$. sp. cf. B. semicostata (see Tjalsma and Lohmann, 1983, pl. 13, figs. 6-7) were also found. In Sample 605-14-7, bottom, the benthic fauna is dominated by $B$. sp. cf. $B$. semicostata.

Bulimina trinitatensis Cushman and Jarvis (Plate 2, Fig. 5). Cushman and Jarvis, 1928, p. 102, pl. 14, figs. 12a-b. See remarks under $B$. impendens.

Bulimina tuxpamensis/bradburyi. Bulimina tuxpamensis Cole, 1928 p. 212 , pl. 32 , fig. 23. Bulimina bradburyi Martin, 1943, p. 109 pl. 6, fig. 4a-b. The two species are close in morphology and have not been differentiated. Rare.

Buliminella grata Parker and Bermudez (Plate 2, Fig. 9). Parker and Bermudez, 1937, p. 515, pl. 59, figs. 6a-c. Scattered occurrence, with occasionally high abundance peaks $(27 \%$ of the total fauna in Sample 605-11,CC).

Chrysalogonium longiscatum Cushman and Jarvis (Plate 5, Fig. 13). Cushman and Jarvis, 1934, p. 74, pl. 10, fig. 12. Rare.

Chrysalogonium tenuicostatum Cushman and Bermudez (Plate 5, Fig. 8). Cushman and Bermudez, 1936b, p. 27, pl. 5, figs. 3-5. Rare.

Cibicidoides grimsdalei (Nuttall) (Plate 3, Figs. 13, 14). Cibicides grims dalei Nuttall, 1930, p. 291, pl. 25, figs. 7-8, 11. Rare occurrence in the upper part of the section.

Cibicidoides havanensis (Cushman and Bermudez) (Plate 3, Figs. 11, 12) Cibicides havanensis Cushman and Bermudez, 1937, p. 28, pl. 3, figs. 1-3. Relatively large species that may have strongly convex dorsal side. Scattered occurrence throughout the section.

Cibicidoides sp. aff. C. laurisae (Mallory) (Plate 3, Fig. 8). Cibicides laurisae Mallory, 1959, p. 267, pl. 24, figs. 8a-c. Planoconvex. Very rare.

Cibicidoides spp. Includes several unidentified species, mostly from the poorly preserved lower part of the section.

Cibicidoides subspiratus (Nuttall) (Plate 3, Figs. 15, 16). Cibicides subspiratus Nuttall, 1930, p. 292, pl. 25, figs. 9-10, 14. Rare.

Cibicidoides tuxpamensis (Cole) (Plate 3, Figs. 5-7). Cibicides tuxpamensis Cole, 1928 , p. 219 , pl. 1, figs. $2-3$; pl. 3, figs. 5-6. The two morphotypes described by Tjalsma and Lohmann (1983, p. 28) are present in our material. Common.

Cibicidoides ungerianus (d'Orbigny) (Plate 3, Figs. 9, 10). Rotalina ungeriana d'Orbigny, 1846, p. 157, pl. 8, figs. 16-18. Transitional forms between $C$. ungerianus and $C$. tuxpamensis with a higher conical test than typical $C$. ungerianus, as noted by Miller (1983), are included in $C$. ungerianus. Frequent to common.

Cibicidoides westi (Howe). Cibicides westi Howe, 1939, p. 88, pl. 13, figs. 20-22. Only 1 specimen found in Sample 605 23,CC.

Dentalina spp. and Nodosaria spp. No attempt has been made to subdivide the uniserial nodosarids. Many specimens are broken. Common to abundant throughout the section.

Ellipsodimorphina subcompacta Liebus (Plate 5, Fig. 15). Liebus, 1922, p. 57, pl. 2, fig. 13. Rare.

Ellipsoglandulina multicostata (Galloway and Morrey) (Plate 5, Fig. 14). Daucina multicostata Galloway and Morrey, 1929, p. 42, pl. 6, fig. 13. Rare.

Gaudryina sp. cf. G. laevigata Franke (Plate 1, Fig. 2). cf. Gaudryina laevigata Franke, 1914, p. 431, pl. 27, figs. 1, 2. Coarsely agglutinated. Included are forms larger than is typical, that become more or less biserial. These forms can be assigned to $G$. sp. cf. G. pyramidata sensu Tjalsma and Lohmann (1983, p. 31, pl. 8, figs. 2a-b). Present in both units, but more common in Unit III.

Gaudryina pyramidata Cushman (Plate 1, Fig. 1), Gaudryina laeviga ta Franke var. pyramidata Cushman, 1926, p. 587, pl. 16, figs. 8a-b. Rather common in Unit III, rare in Unit II.

Gavelinella capitata (Guembel) (Plate 4, Figs. 3, 4). Rotalina capitato Guembel, 1868 , p. 653 , pl. 2, figs. 92 a-c. Relatively rare throughout the section, but more common in Unit III.

Gavelinella micra (Bermudez) (Plate 4, Figs. 5, 6). Cibicides micrus Bermudez, 1949, p. 302, pl. 24, figs. 34-36. Found only in Unit II, where it constitutes up to $8 \%$ of the fauna.

Gavelinella semicribrata (Beckmann) (Plate 4, Figs. 7, 8). Anomalina pompilioides Galloway and Heminway var. semicribrata Beckmann, 1953, p. 400, pl. 27, fig. 3, text-figs. 24-25. Scattered occurrence in both units. Rather common in the middle part of the section (Samples 605-19,CC-605-25,CC).

Globocassidulina subglobosa (Brady) (Plate 5, Fig. 1). Cassidulina subglobosa Brady, 1884, p. 430, pl. 54, figs. 17a-c. Most specimens are small. Rare in Unit III. More frequent in Unit II (up to 8\%).

Glomospira charoides (Jones and Parker) (Plate 1, Fig. 8). Trochammina squamata Jones and Parker var. charoides Jones and Parker, 1860 , p. 304. Confined to Unit III. Frequent.

Gyroidinoides spp. No attempt has been made to split the group into species. Frequent to common throughout the section (up to $8 \%$ ).

Hanzawaia cushmani (Nuttall) (Plate 4, Figs. 15, 16). Cibicides cushmani Nuttall, 1930, p. 291, pl. 25, figs. 3, 5-6. Only found in Unit II. In Sample $605-18, \mathrm{CC}$ it constitutes $16 \%$ of the fauna

Karreriella chapapotensis (Cole) (Plate 1, Figs. 5, 6). Textularia chapapotensis Cole, 1928, p. 206, pl. 33, fig. 9. According to Tjalsma and Lohmann (1983, p. 32) $K$. monumentensis Mallory (1959) (pl. 9, fig. 3) may be the microspheric generation of $K$. chapapotensis. Rare.

Karreriella subglabra (Guembel) (Plate 1, Fig. 7). Gaudryina subglabra Guembel, 1868, p. 602, pl. 1, figs. 4a-b. Rare. More frequent in Unit II.

Lagena spp. and Fissurina spp. Irregularly present throughout the section. Rare.

Lenticulina spp. This group contains several unidentified species of Lenticulina. Lenticulina spp. are common to abundant throughout the section.

Marginulina eximia Neugeboren (Plate 5, Fig. 7). Neugeboren, 1851, p. 129 , pl. 4, fig. 17. Rare.

Nodosarella subnodosa (Guppy) (Plate 5, Fig. 16). Ellipsoidina subnodosa Guppy, 1894, p. 650, pl. 61, fig. 12. Rare.

Nodosaria latejugata Guembel (Plate 5, Fig. 12). Guembel, 1868, p. 619 , pl. 1, fig. 32. Rare.

Nonion havanense Cushman and Bermudez (Plate 5, Fig. 2). Cushman and Bermudez, 1937, p. 19, pl. 2, figs. 13-14. Occurring throughout the section.

Nuttallides truempyi (Nuttall) (Plate 3, Figs. 1-3). Eponides truempyi Nuttall, 1930, p. 287, pl. 24, figs. 9, 13-14. Both lenticular as well as planoconvex morphotypes are present. Forms that can be assigned to Nuttallides crassaformis have been included in N. truem$p y i$, as it was difficult to distinguish both species because of poor preservation. Consistently present throughout the section. Common to abundant (up to $19 \%$ ).

Oridorsalis umbonatus (Reuss) (Plate 5, Figs. 3, 4). Rotalina umbonata Reuss, 1851 , p. 75 , pl. 5, fig. 35. Common throughout the section. Often accompanied by other Oridorsalis spp..

Orthomorphina havanensis (Cushman and Bermudez) Nodogenerina havanensis Cushman and Bermudez, 1937, p. 14, pl. 1, figs. 47, 48. Rare.

Orthomorphina sp. cf. O. heterosculpta (Bermudez) (Plate 5, Fig. 17). cf. Nodogenerina heterosculpta Bermudez, 1949, p. 178, pl. 11, fig. 58. Rare.

Osangularia mexicana (Cole) (Plate 3, Fig. 4). Pulvinulinella culter (Parker and Jones) var. mexicana Cole, 1927, p. 31, pl. 1, figs. 15, 16. Present throughout the section. Also other Osangularia spp. are present.

Plectina elongata Cushman and Bermudez (Plate 1, Fig. 3). Cushman and Bermudez, 1936a, p. 58, pl. 10, figs. 22-24. Confined to Unit II. Rather common.

Plectina nuttalli Cushman and Stainforth (Plate 1, Fig. 4). Cushman and Stainforth, 1951, p. 144, pl. 25, figs. 26a-27. Rare.

Pleurostomella acuta Hantken (Plate 5, Fig. 11). Hantken, 1875, p. 44, pl. 13, fig. 18. Rare.

Pleurostomella incrassata Hantken (Plate 5, Fig. 10). Hantken, 1884 p. 146, pl. 1, figs, 4, 7. Rare.

Pleurostomella subcylindrica (Cushman) (Plate 5, Fig. 9). Nodosarella subcylindrica Cushman, 1943, p. 91, pl. 16, figs. 4, 5. Rare.

Polymorphinids. This group consists mainly of Guttulina spp. It constitutes up to $5 \%$ of the fauna in the upper part of the section.

Pullenia eocenica Cushman and Siegfus (Plate 4, Figs. 9, 10, 13, 14). Cushman and Siegfus, 1939, p. 31, pl. 7, figs. 1a-b. Common in Unit II. Specimens have a nonlobate outline and a variable degree of compression.

Pullenia quinqueloba (Reuss) (Plate 4, Figs. 11, 12). Nonionina quinqueloba Reuss, 1851 , p. 71 , pl. 5, figs. 31a-b. Rare to common throughout the section. 
Ramulina globulifera Brady (Plate 1, Fig. 14). Brady, 1879, p. 58, pl. 8, figs. 32, 33. Rare in Unit II.

Spiroplectammina cubensis Cushman and Bermudez (Plate 1, fig. 11). Spiroplecta cubensis Cushman and Bermudez, 1937, pl. 13, pl. 1, figs. 44-46. Rare.

Spiroplectammina spectabilis (Grzybowski) (Plate 1, Figs. 9, 10). Spiroplecta spectabilis Grzybowski, 1898, p. 293, pl. 12, fig. 12. Rather common.

Stilostomella aculeata (Cushman and Renz) (Plate 2, Fig. 14). Ellipsonodosaria nuttalli Cushman and Jarvis var. aculeata Cushman and Renz, 1948, p. 32, pl. 6, fig. 10. Rare.

Stilostomella gracillima (Cushman and Jarvis) (Plate 2, Fig. 15). Ellipsonodosaria nuttalli Cushman and Jarvis var. gracillima Cushman and Jarvis, 1934, p. 72, pl. 10, figs. 7a-b. Rather common.

Stilostomella modesta (Bermudez) (Plate 2, Fig. 17). Ellipsonodosaria modesta Bermudez, 1937, p. 238, pl. 20, fig. 3. Rare.

Stilostomella subspinosa (Cushman) (Plate 2, Fig. 16) Ellipsonodosaria subspinosa Cushman, 1943, p. 92, pl. 16, figs. 6-7b. Rare.

Stilostomella verneuili (d'Orbigny). Dentalina verneuili d'Orbigny, 1846 , p. 48 , pl. 2 , figs. 7,8 . Rare.

Tappanina selmensis (Cushman) (Plate 1, Fig. 15). Bolivinita selmensis Cushman, 1933, p. 58, pl. 7, figs. 3, 4. Confined to the lowermost part of the section (Samples 605-41,CC, 605-43,CC).

Trifarina wilcoxensis (Cushman and Ponton) (Plate 2, Fig. 13). Pseudouvigerina wilcoxensis Cushman and Ponton, 1932, p. 66, pl. 8, fig. 18. Rare.

Turrilina robertsi (Howe and Ellis) (Plate 2, Fig. 10). Bulimina robertsi Howe and Ellis in Howe, 1939, p. 63, pl. 8, figs. 32, 33. Rare.

Uvigerina elongata Cole (Plate 2, Fig. 12). Cole, 1927, p. 26, pl. 4, figs. 2-3. Rather common in Unit II.

Uvigerina rippensis Cole (Plate 2, Fig. 11). Cole, 1927, p. 11, pl. 2, fig. 16. Only found in the uppermost sample $(605-6, \mathrm{CC})$, where it constitutes $5 \%$ of the fauna.

Vagulinopsis decorata (Reuss). Cristellaria decorata Reuss, 1855, p. 269, pl. 8, fig. 16, pl. 9, figs. 1, 2. Only two specimens were encountered, in Samples 605-29-5, bottom, and 605-30,CC, respectively.

Vulvulina mexicana Nuttall (Plate 1, Fig. 16). Vulviulina pectinata var. mexicana Nuttall, 1930, p. 280, pl. 23, fig. 7. Rare.

Vulvulina spinosa Cushman (Plate 1, Figs. 12, 13). Cushman, 1927b, p. 111, pl. 23, fig. 1. Rather common throughout the section.

\section{ACKNOWLEDGMENTS}

I thank the shipboard scientists and technicians for sampling the cores, and I am grateful to J. E. van Hinte for providing me with the material and suggestions.

\section{REFERENCES}

Beckmann, J. P., 1953. Die Foraminiferen der Oceanic Formation (Eocaen-Oligocaen) von Barbados, Kl. Antillen. Eclogae Geol. Helv., 46(2):301-412.

Berggren, W. A., 1972. Cenozoic biostratigraphy and paleobiogeography of the North Atlantic. In Laughton, A. S., Berggren, W. A., et al., Init. Repts. DSDP, 12: Washington (U.S. Govt. Printing Office), 965-1001.

Berggren, W. A., and Aubert, J., 1975. Paleocene benthonic foraminiferal biostratigraphy, paleobiogeography, and paleoecology of Atlantic-Tethyan regions: Midway-type fauna. Palaeogeogr., Palaeoclimatol., Palaeoecol., 18:73-192.

Berggren, W. A., Kent, D. V., Flynn, J. J., and Van Couvering, J. A., 1985. Cenozoic geochronology. Geol. Soc. Am. Bull., 96:14071418 .

Bermudez, P. J., 1937. Nuevas especies de foraminiferos del Eocene des las cercanias Guanajay, Provincia Pinar del Río, Cuba. Soc. Cub. Hist. Nat., Mem. (Havana), 11:237-247.

1949. Tertiary smaller Foraminifera of the Dominican Republic. Cushman Lab. Foram. Res., Spec. Publ., 25.

Boersma, A., 1977. Eocene to early Miocene benthic foraminifera DSDP Leg 39, South Atlantic. In Supko, P. R., Perch-Nielsen, K., et al., Init. Repts. DSDP, 39: Washington (U.S. Govt. Printing Office), 643-656.

Boltovskoy, E., 1980. On the benthonic bathyal-zone foraminifera as stratigraphic guide fossils. J. Foram. Res., 10:163-172.

Brady, H. B., 1879. Notes on some of the reticularian Rhizopoda of the "Challenger" expedition. Q. J. Microsc. Sci., London, N. Ser., $19,20-63$.
1884. Report on the Foraminifera Dredged by H.M.S. Challenger, During the years 1873-1876. Rep. Voy. Challenger, Zool., 9.

Cole, W. S., 1927. A foraminiferal fauna from the Guayabal Formation in Mexico. Bulls. Am. Paleontol., 14(51):1-47.

1928. A foraminiferal fauna from the Chapapote Formation in Mexico. Bulls. Am. Paleontol., 14(53):203-233.

Corliss, B. H., 1981. Deep-sea benthonic foraminiferal fauna turnover near the Eocene/Oligocene boundary. Mar. Micropaleontol., 6:367384.

Cushman, J. A., 1926. The foraminifera of the Velasco Shale of the Tampico Embayment. Am. Assoc. Pet. Geol. Bull., 10:581-612. 1927a. American Upper Cretaceous species of Bolivina and related species. Cushman Lab. Foram. Res. Contr., 2:85-91.

, 1927b. New and interesting foraminifera from Mexico and Texas. Cushman Lab. Foram. Res., 3(2):107-118.

1933. New American Cretaceous foraminifera. Cushman Lab. Foram. Res. Contr., 9:49-64.

1943. Some new foraminifera from the Tertiary of the island of St. Croix. Cushman Lab. Foram. Res. Contr., 19:90-93.

Cushman, J. A., and Bermudez, P. J., 1936a. Additional new species of foraminifera and a new genus from the Eocene of Cuba. Cushman Lab. Foram. Res. Contr., 12:55-63.

1936b. New genera and species of foraminifera from the Eocene of Cuba. Cushman Lab. Foram. Res. Contr., 12:27-38. 1937. Further new species of foraminifera from the Eocene of Cuba. Cushman Lab. Foram. Res. Contr., 13:1-29.

Cushman, J. A., and Jarvis, P. W., 1928. Cretaceous foraminifera from Trinidad. Cushman Lab. Foram. Res. Contr., 4:85-103.

1934. Some interesting new uniserial foraminifera from Trinidad. Cushman Lab. Foram. Res. Contr., 10:71-75.

Cushman, J. A., and Parker, F. L., 1936. Some American Eocene buliminas. Cushman Lab. Foram. Res. Contr., 12:39-45. 1939. Bulimina macilenta Cushman and Parker, a new name. Cushman Lab. Foram. Res. Contr., 15:93-94.

Cushman, J. A., and Ponton, G. M., 1932. An Eocene foraminiferal fauna of Wilcox age from Alabama. Cushman Lab. Foram. Res. Contr., 8:51-72.

Cushman, J. A., and Renz, H. H., 1948. Eocene foraminifera of the Navet and Hospital Hill formations of Trinidad, B.W.I. Cushman Lab. Foram. Res. Spec. Publ., 24.

Cushman, J. A., and Siegfus, S. S., 1939. Some new and interesting foraminifera from the Kreyenhagen Shale of California. Cushman Lab. Foram. Res. Contr., 15:23-40.

Cushman, J. A., and Stainforth, R. M., 1945. The Foraminifera of the Cipero Marl Formation of Trinidad, British West Indies. Cushman Lab. Foram. Res. Spec. Publ., 14.

1951. Tertiary foraminifera of coastal Ecuador: Part I. Eocene. J. Paleontol., 25:129-164.

Douglas, R. G., 1973. Benthonic foraminiferal biostratigraphy in the central North Pacific, Leg 17, Deep Sea Drilling Project. In Winterer, E. L., Ewing, J. I., et al., Init. Repts. DSDP, 17: Washington (U.S. Govt. Printing Office), 607-671.

Franke, A., 1914. Die Foraminiferen und Ostracoden des Emschers, besonders von Obereving und Derne nordlich Dortmund. Z. Dtsch. Geol. Ges., Reihe A, Abh., 66(3):428-443.

Galloway, J. J., and Morrey, M., 1929. A Lower Tertiary foraminiferal fauna from Manta, Ecuador. Bulls. Amer. Paleontol., 15(55):7-56.

Grzybowski, J., 1898. Foraminifera of the oil-bearing beds in the vicinity of Krosno. Akad. Umiej. Krakowie, Wydz. Mat.-Przyr., Rozpr., 33(ser.2,13):257-305. (In Polish)

Guembel, C. W., 1868. Beitrage zur Foraminiferenfauna der nordalpinen Eocaengebilde. K. Bayer. Akad. Wiss., Munden, Math-Phys. Kl., Abh., 10(2):581-730.

Guppy, R. J. L., 1894. On some foraminifera from the Microzoic deposits of Trinidad, West Indies. Zool. Soc. London., Proc., pp. 647-652.

Hantken, M., von, 1875. Die Fauna der Clavulina szaboi Schichten. Theil I. Foraminiferen. Mitt. Jb. K. Ung. Geol. Anst, 4:1-93. 1884. Die Clavulina szaboi-Schichten im Gebiete der Euganeen und der Meeralpen und die cretacische Scaglia in den Euganeen. Math. Naturw. Ber. Ungarn, 2:82-109.

Hardenbol, J., Vail, P. R., and Ferrer, J., 1981. Interpreting paleoenvironments, subsidence history and sea-level changes of passive margins from seismic and biostratigraphy. Proc. 26th Int. Geol. Con- 
gress, Geology of Continental Margins Symposium, Paris, July 717, 1980. Oceanol. Acta, 3:33-44.

Hinte, J. E. van, Wise, S. W., et al., 1985. Deep sea drilling on the upper continental rise off New Jersey: DSDP Sites 604 and 605. Geology, 13:397-400.

Howe, H. V., 1939. Louisiana Cook Mountain Eocene foraminifera. Louisiana Dept. Conserv. Geol. Surv., Geol. Bull. (New Orleans), $14: 1-122$.

Jones, R., and Parker, W. K., 1860. On the rhizopodal fauna of the Mediterranean, compared with that of the Italian and some other Tertiary deposits. Q. J. Geol. Soc. London, 16:292-307.

Liebus, A., 1922. Zur Altersfrage der Flyschbildungen im nordöstlichen Mähren. Lotos, Naturw. Z., 70:1-70.

Mallory, V. S., 1959. Lower Tertiary Biostratigraphy of the California Coast Ranges: Tulsa (Am. Assoc. Pet. Geol.).

Martin, L. T., 1943. Eocene foraminifera from the type Lodo Formation, Fresno County, California. Stanford Univ. Ser., Geol. Sci., 3(3): $93-125$.

Miller, K. G., 1983. Eocene-Oligocene paleoceanography of the deep Bay of Biscay; benthic foraminiferal evidence. Mar. Micropaleontol., 7:403-440.

Miller, K. G., Curry, W. B., and Ostermann, D. R., 1985. Late Paleogene (Eocene to Oligocene) benthic foraminiferal paleoceanography of the Goban Spur region, Deep Sea Drilling Project Leg 80 . In Graciansky, P. C. de, Poag, C. W., et al., Init. Repts. DSDP, 80: Washington (U.S. Govt. Printing Office), 505-538.

Neugeboren, J. L., 1851. Foraminiferen von Ober-Lapugy; dritter Artikel (Fortsetzung). Siebenb. Ver. Naturw. Hermannstadt, Verh. Mitt., Jahrg. 2(8):140-145.

Nuttall, W. L. F., 1930. Eocene foraminifera from Mexico. J. Paleontol., 4(3):271-293.

Orbigny, A. d', 1846. Foraminiferes Fossiles du Bassin Tertiaire de Vienne (Autriche): Paris (Gide et Comp.).
Parker, F. L., and Bermudez, P. J., 1937. Eocene species of the genera Bulimina and Buliminella from Cuba. J. Paleontol., 11(6):513-516.

Proto-Decima, F., and Bolli, H. M., 1978. Southeast Atlantic DSDP Leg 40 Paleogene benthic foraminifers. In Bolli, H. M., Ryan, W. B. F., et al., Init. Repts. DSDP, 40: Washington (U.S. Govt. Printing Office), 783-809.

Resig, J. M. 1976. Benthic foraminiferal stratigraphy, eastern margin, Nazca Plate. In Yeats, R. S., Hart, S. R., et al., Init. Repts. DSDP, 34: Washington (U.S. Govt. Printing Office), 743-759.

Reuss, A. E., 1851. Ueber die fossilen Foraminiferen und Entomostraceen der Septarienthone der Umgegend von Berlin. Z. Dtsch. Geol. Ges., 3:49-92.

1855. Ein Beitrag zur genaueren Kentniss der Kreidegebilde Mecklenburgs. Z. Dtsch. Geol. Ges., 7(1):261-292.

Schnitker, D., 1979. Cenozoic deep water benthic foraminifera, Bay of Biscay. In Montadert, L., Roberts, D. G., et al., Init. Repts. DSDP, 48: Washington (U.S. Govt. Printing Office), 377-413.

Schnitker, D., and Tjalsma, L. R. C., 1980. New genera and species of benthic foraminifers from Paleocene and Eocene deep water deposits. J. Foram. Res., 10(3):235-241.

Snyder, S. W., Müller, C., and Miller, K. G., 1985. Biostratigraphy and paleoceanography across the Eocene/Oligocene boundary a Deep Sea Drilling Project Site 549. In Graciansky, P. C. de, Poag, C. W., et al., Init. Repts. DSDP, 80: Washington (U.S. Govt. Printing Office), 567-572.

Tjalsma, R. C., and Lohmann, G. P., 1983. Paleocene-Eocene Bathyal and Abyssal Benthic Foraminifera from the Atlantic Ocean. Micropaleontology, Spec. Publ., 4.

Date of Initial Receipt: 16 July 1985

Date of Acceptance: 12 June 1986 

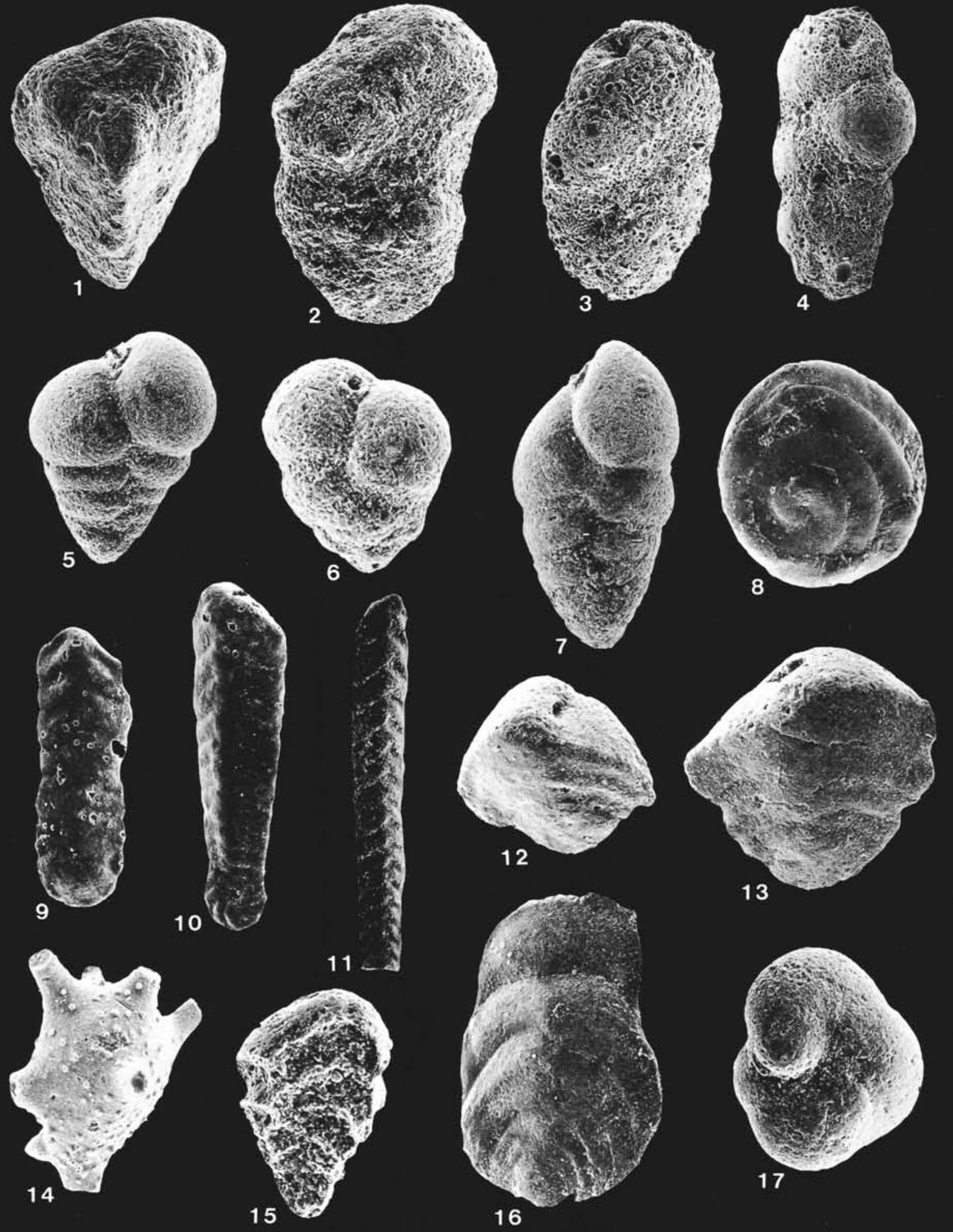

13

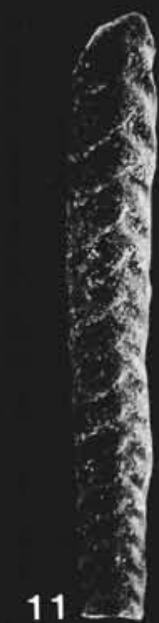



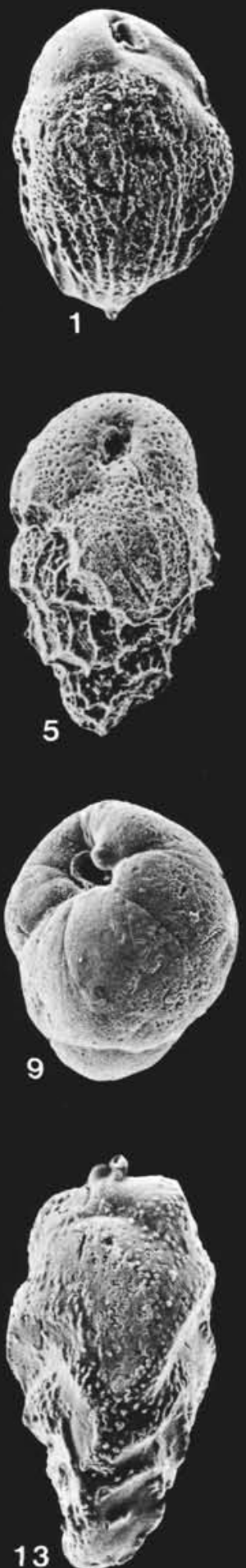
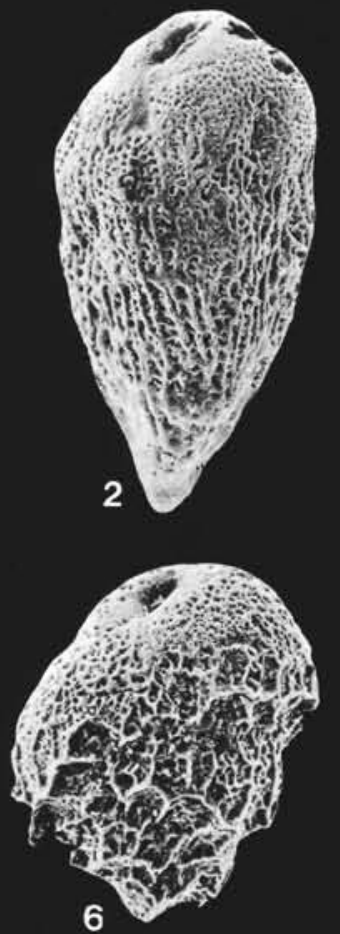

6
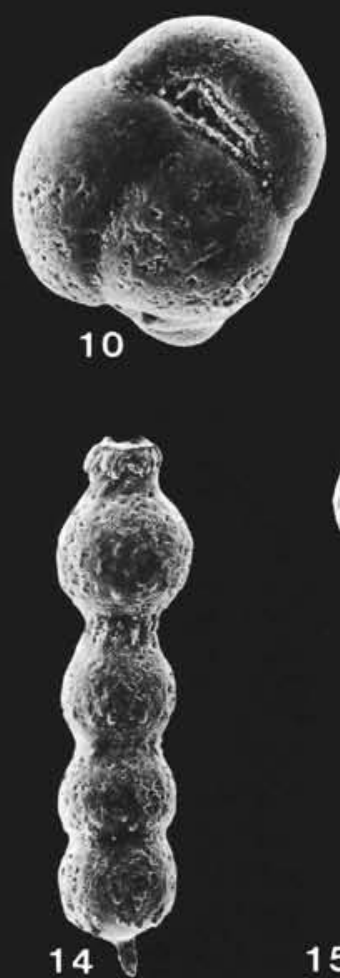
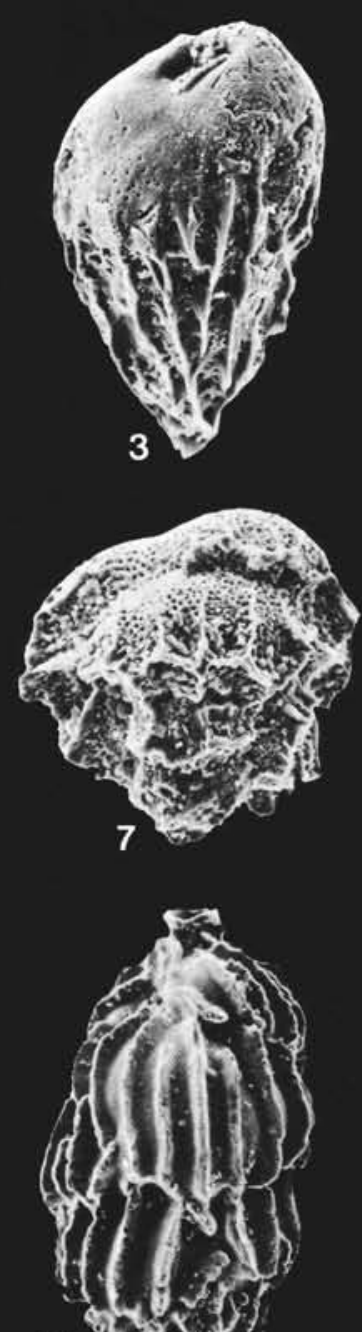

11 Then
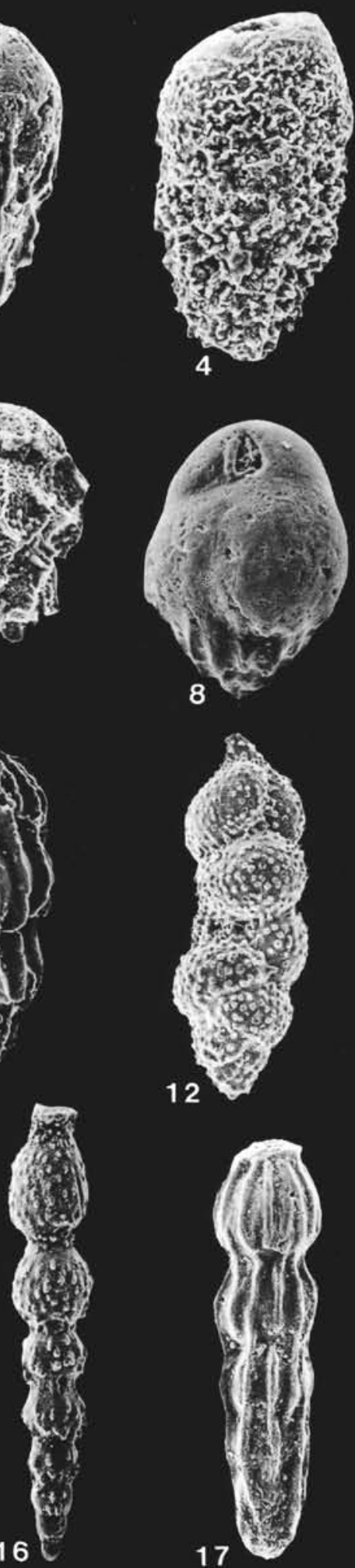

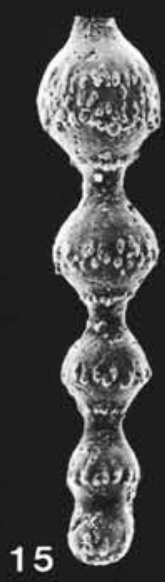

Plate 2. 1. Bulimina $\mathrm{sp}$. cf. B. semicostata Nuttall, Sample $605-14-7$, bottom, $\times 128$. 2. Bulimina semicostata Nuttall, Sample $605-13, \mathrm{CC}, \times 96$. 3. Bulimina alazanensis Cushman, Sample $605-17, \mathrm{CC}, \times 192$. 4. Bulimina huneri Howe, Sample $605-6, \mathrm{CC}, \times 128$. 5. Bulimina trinitatensis Cushman and Jarvis, Sample 605-6,CC, $\times 128$. 6, 7. Bulimina impendens Parker and Bermudez, Sample 605-6,CC, (6) $\times 128 .(7) \times 192$. 8 . Bulimina macilenta Cushman and Parker, Sample 605-7,CC, $\times 128$. 9. Buliminella grata Parker and Bermudez, Sample $605-11, \mathrm{CC}, \times 80$. 10. Turrilina robertsi (Howe and Ellis), Sample $605-13, \mathrm{CC}, \times 160$. 11. Uvigerina rippensis Cole, Sample $605-6, \mathrm{CC}, \times 80$. 12. Uvigerina elongata Cole, Sample 605-10,CC, $\times 96$. 13. Trifarina wilcoxensis (Cushman and Ponton), Sample 605-9-5, bottom, $\times 128$. 14. Stilostomella aculeata (Cushman and Renz), Sample 605-21,CC, $\times 64$. 15. Stilostomella gracillima (Cushman and Jarvis), Sample 605-8-1, bottom; $\times 64$. 16 . Stilostomella subspinosa (Cushman), Sample 605-8-1, bottom, $\times 64$. 17. Stilostomella modesta (Bermudez), Sample 605-7,CC, $\times 96$. 


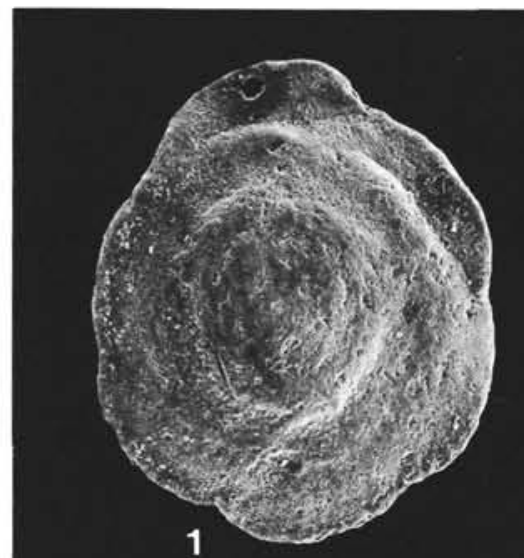

1

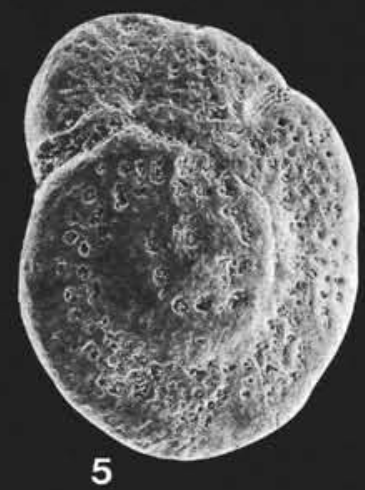

5

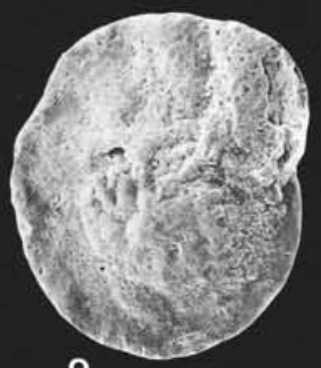

9

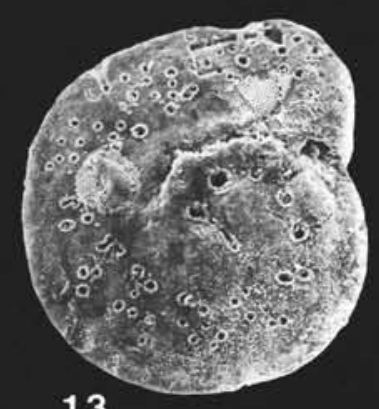

13
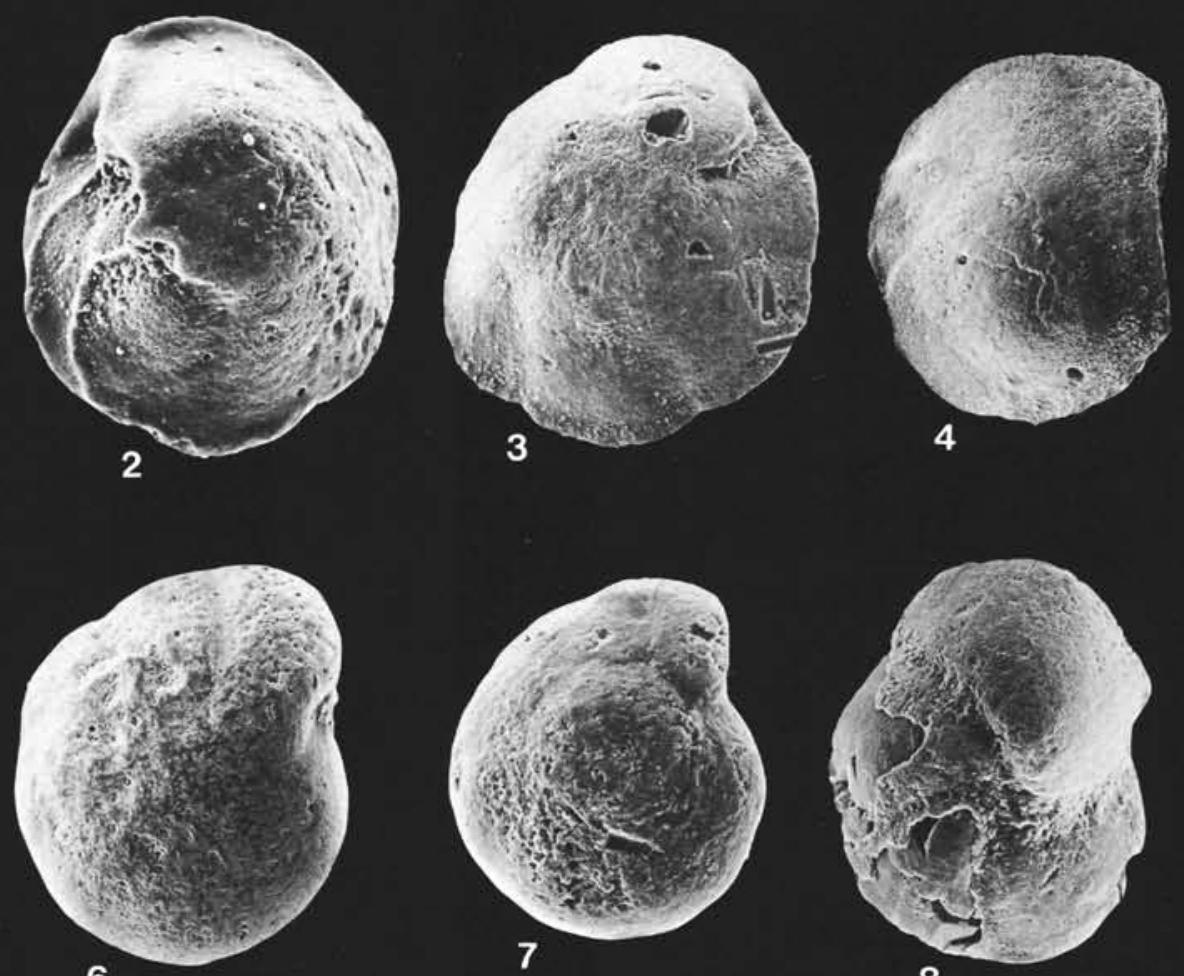

6
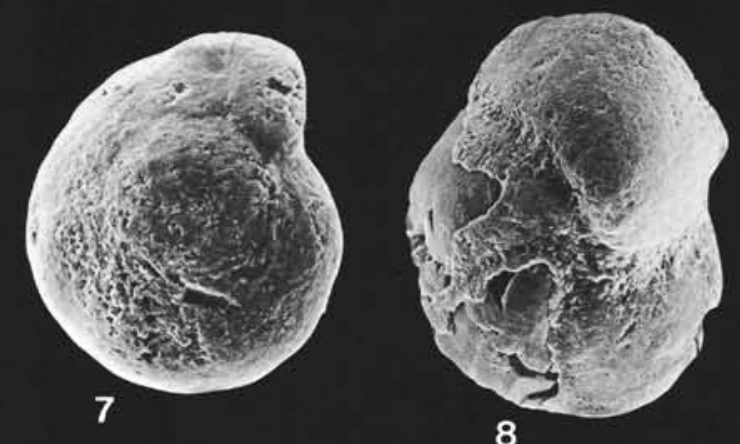

8

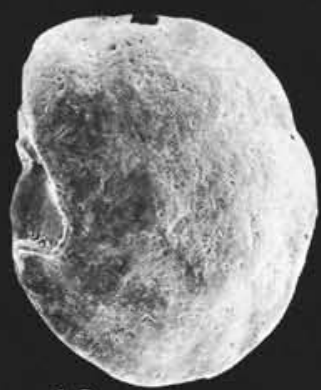

10

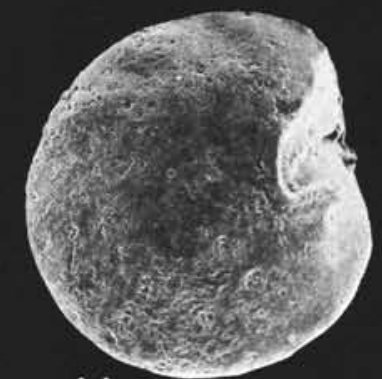

11

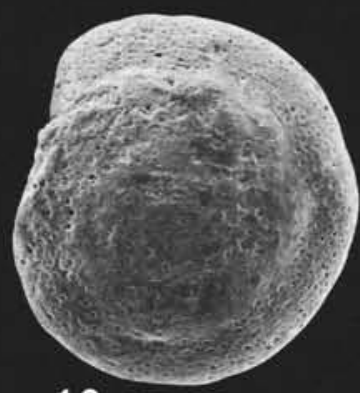

12
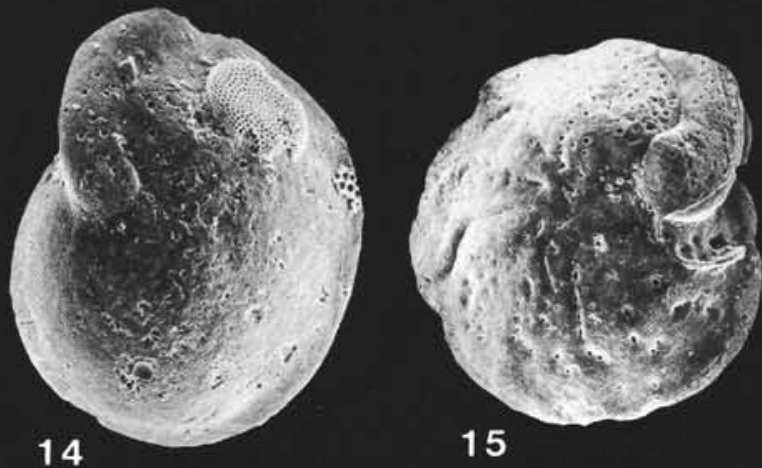

15

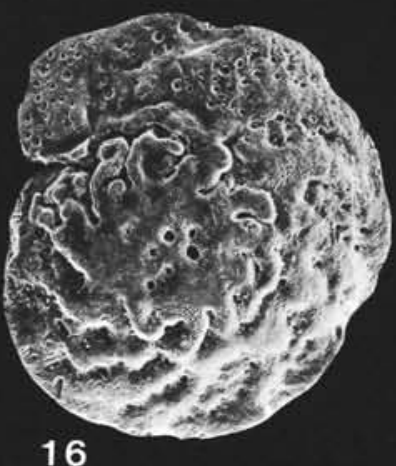

Plate 3. 1-3. Nuttallides truempyi (Nuttall), Sample 605-16,CC, $\times 96,(1)$ dorsal side; $(2,3)$ ventral side. 4. Osangularia mexicana (Cole), Sample 605-13,CC, $\times 64$. 5-7. Cibicidoides tuxpamensis (Cole), (5-6) Sample 605-26-3, 60-62 cm, megalospheric morphotype, $\times 64$, (5, dorsal side; 6, ventral side); (7) Sample 605-9-5, bottom, ventral side, microspheric morphotype, $\times 128$. 8. Cibicidoides sp. aff. C. laurisae (Mallory), Sample 605-27,CC, ventral side, $\times 96$. 9, 10. Cibicidoides ungerianus (d'Orbigny), Sample 605-23,CC, $\times 64$, (9) dorsal side; (10) ventral side. 11, 12. Cibicidoides havanensis (Cushman and Bermudez), Sample 605-23,CC, $\times 64$, (11) ventral side; (12) dorsal side. 13, 14. Cibicidoides grimsdalei (Nuttall), Sample 605-12,CC, $\times 96,(13)$ dorsal side; (14) ventral side. 15, 16. Cibicidoides subspiratus (Nuttall), Sample 605-12,CC, $\times 48$, (15) ventral side; (16) dorsal side. 


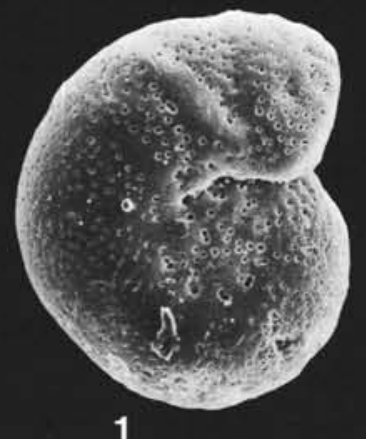

1

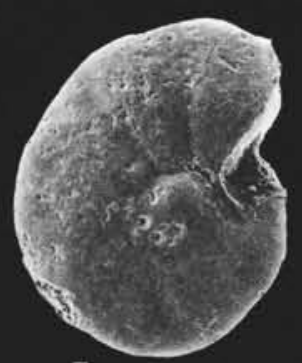

5

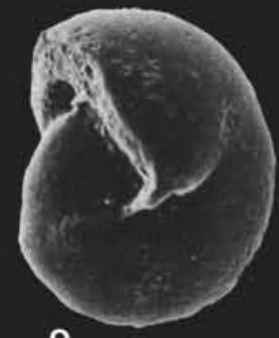

9

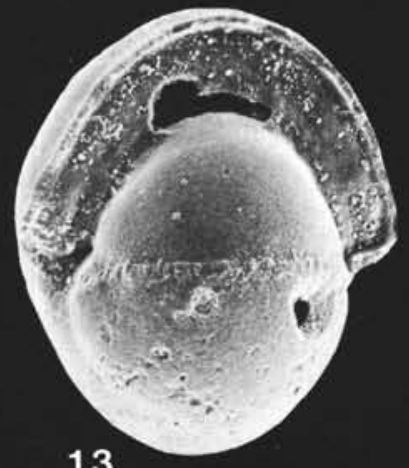

13

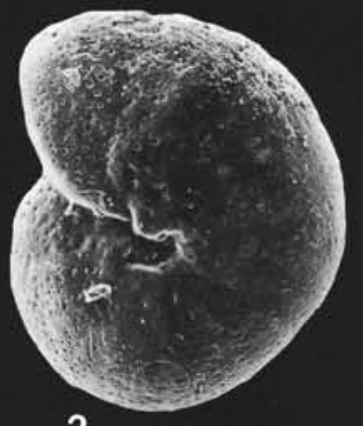

2

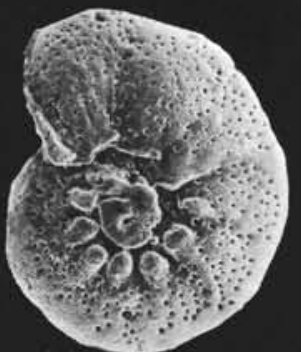

6

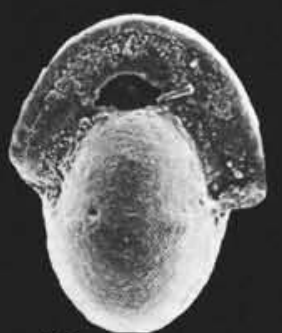

10

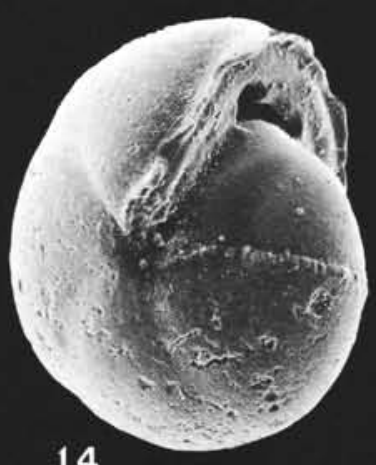

14

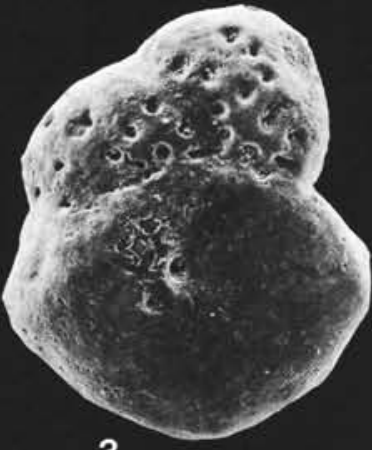

3

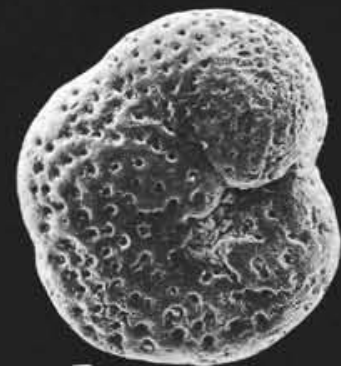

7

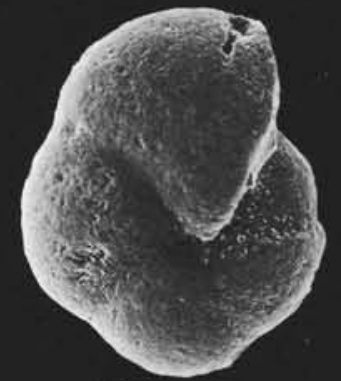

11

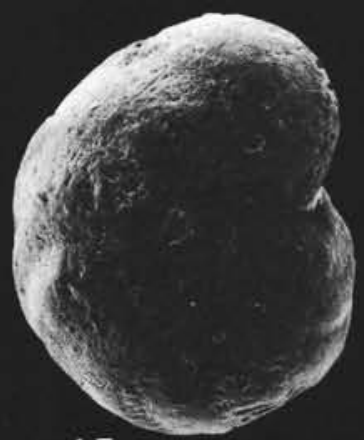

15

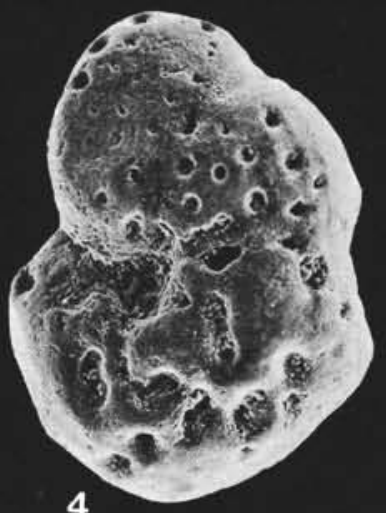

4

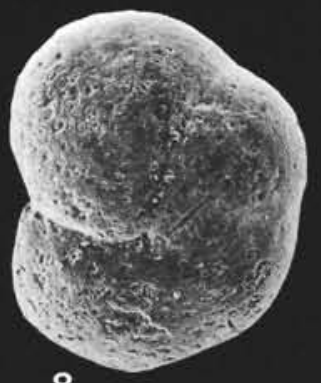

8

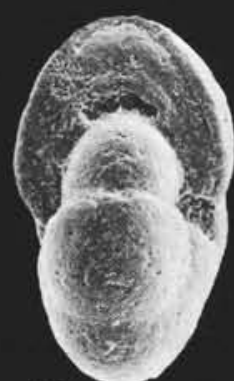

12

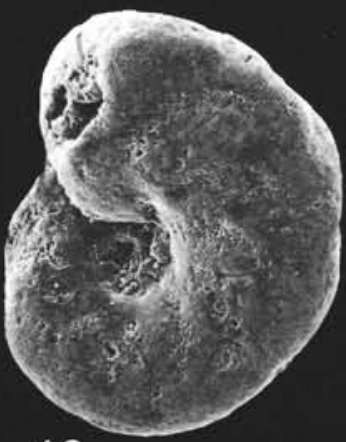

16

Plate 4. 1, 2. Anomalina spissiformis Cushman and Stainforth, Sample 605-10,CC, $\times 64,(1)$ dorsal side; (2) ventral side. 3, 4. Gavelinella capitata Guembel, Sample 605-16,CC, $\times 80$, (3) dorsal side; (4) ventral side. 5, 6. Gavelinella micra (Bermudez), Sample 605-13,CC, $\times 64,(5)$ dorsal side; (6) ventral side. 7, 8. Gavelinella semicribrata (Beckmann), $\times 80$, (7) Sample 605-21,CC, coarsely perforated ventral side; (8) Sample 605-22,CC, smooth dorsal side. 9, 10, 13, 14. Pullenia eocenica Cushman and Siegfus, $(9,10)$ Sample 605-14-7, bottom; $\times 96$ (10, side view); $(13,14)$ Sample $605-6, C C, \times 112$ (13, side view). 11, 12. Pullenia quinqueloba (Reuss), Sample 605-14-7, bottom $\times 96,(12)$ side view. 15, 16. Hanzawaia cushmani (Nuttall), Sample $605-18, \mathrm{CC}, \times 64,(15)$ ventral side; (16) dorsal side. 


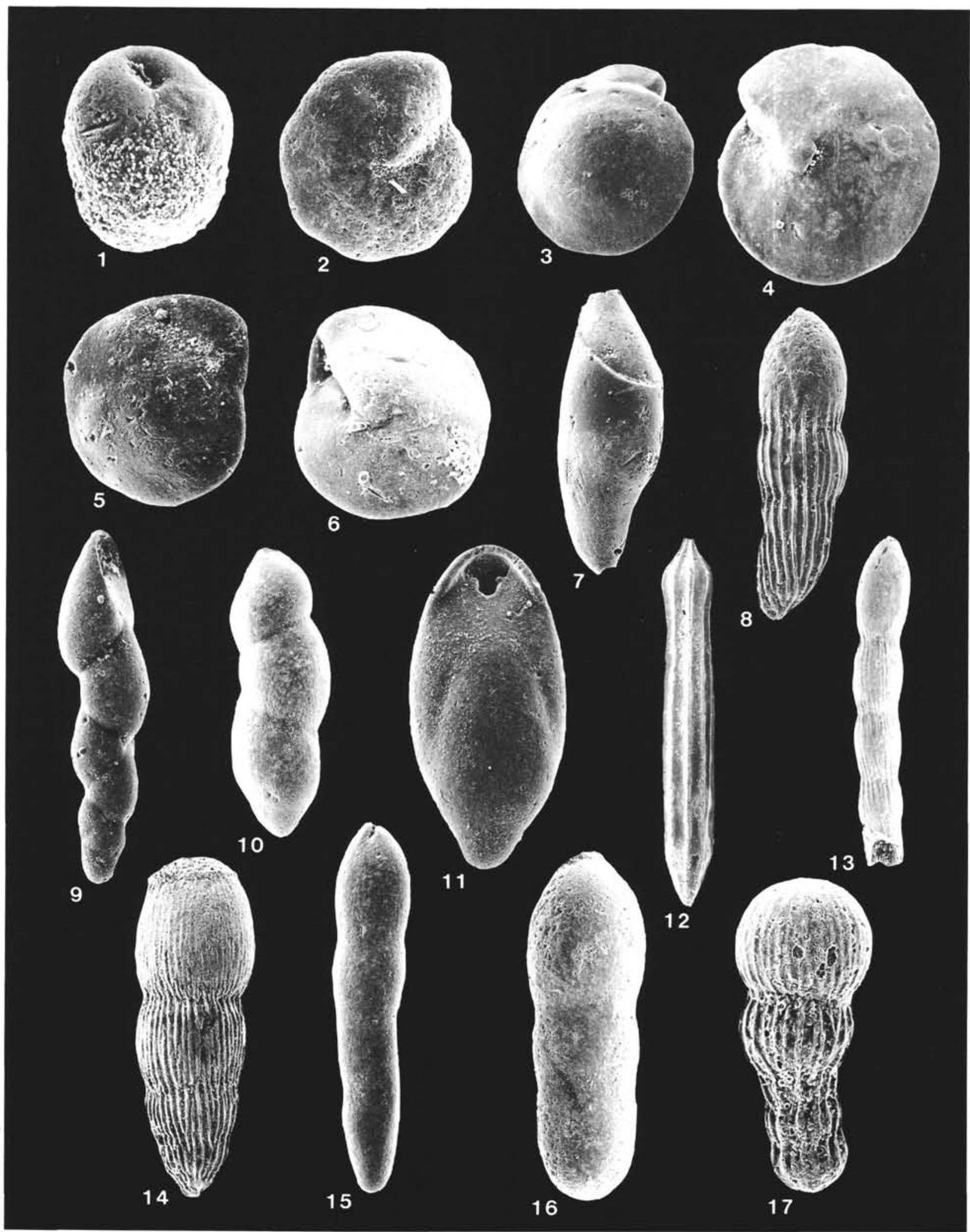

Plate 5. 1. Globocassidulina subglobosa (Brady), Sample 605-13,CC, $\times 192$. 2. Nonion havanense Cushman and Bermudez, Sample 605-25, CC, $\times 112$. 3, 4. Oridorsalis umbonatus (Reuss), Sample 605-6,CC, (3) dorsal side, $\times 80$; (4) ventral side, $\times 96$. 5, 6. Alabamina dissonata (Cushman and Renz), Sample 605-11,CC, $\times 128$, (5) dorsal side; (6) ventral side. 7. Marginulina eximia Neugeboren, Sample 605-6,CC, $\times 80$. 8. Chrysalogonium tenuicostatum Cushman and Bermudez, Sample $605-6, \mathrm{CC}, \times 80$. 9. Pleurostomella subcylindrica (Cushman), Sample $605-6, \mathrm{CC}, \times 96$. 10. Pleurostomella incrassata Hantken, Sample 605-6,CC, $\times 64$. 11. Pleurostomella acuta Hantken, Sample 605-6,CC $\times$ 128. 12. Nodosaria latejugata Guembel, Sample $605-11, C C, \times 26$. 13. Chrysalogonium longiscatum Cushman and Jarvis, Sample $605-20, C C$, $\times 22$. 14. Ellipsoglandulina multicostata (Galloway and Morrey), Sample $605-13, \mathrm{CC}, \times 64$. 15. Ellipsodimorphina subcompacta Liebus, Sample $605-6, \mathrm{CC}, \times 64$. 16. Nodosarella subnodosa (Guppy), Sample 605-25,CC, $\times 80$. 17. Orthomorphina sp. cf. O. heterosculpta (Bermudez), Sample 605-21,CC, $\times 96$. 